Litteratur

. Berg MR. Behandling eller aktiv monitorering ve prostatakreft. Tidsskr Nor Legeforen 2016; 136: 1706

2. Hamdy FC, Donovan JL, Lane JA et al; ProtecT Study Group. 10-Year Outcomes after Monitoring, Surgery, or Radiotherapy for Localized Prostate Cancer. N Engl J Med 2016; 375: 1415-24.

3. Donovan JL, Hamdy FC, Lane JA et al; ProtecT Study Group. Patient-Reported Outcomes after Monitoring. Surgery, or Radiotherapy for Prostate Cancer. N Engl Med 2016; 375: 1425-37.

4. Årsrapport for prostatakreft 2015. https://www.kreftregisteret.no/Generelt/ Publikasjoner/Arsrapport-fra-kvalitetsregistrene/Arsrapport-fraprostatacancerregisteret-/arsrapport-for-prostatakreft-2015/ (11.1.2017).

\section{M.R. Berg svarer:}

Takk for kritisk lesning og utfyllende kommentar til studieomtalen min om to artikler fra PPROTECT-studien (1).

Fosså påpeker at det korrekte faguttrykket er «prostatakreftspesifikk mortalitet», og ikke «tiårsmortalitet som følge av prostatakreft». I arbeidet med å skrive studieomtaler er jeg bevisst på at omtalen skal være relativt lett å forstå for alle leserne, både de med lang erfaring innen det spesifikke fagfeltet og for leger som arbeider innen andre felter eller som er nyutdannet. Dette medfører at studieomtalene mine nok får et mindre vitenskapelig preg, men samtidig (håper jeg) blir lettere tilgjengelig for alle. Det er også viktig for meg at studieomtalene mine er skrevet med norske uttrykk der det lar seg gjøre.

Fosså savner mer utfyllende informasjon om resultatene i de to artiklene som omtales. Hvilke resultater som tas med i en kortfattet studieomtale, er alltid en krevende avveining som kan gjøres på ulike vis. Dette kunne jeg sikkert løst på en annen måte i denne aktuelle studieomtalen, men jeg valgte å gjengi det jeg oppfattet som de aller viktigste funnene. Det er mulig at jeg heller burde tat med noe av informasjonen Fosså etterlyser. Hovedfunnet, at det ikke var noen forskjell i tiårsmortaliteten ved de tre ulike behandlingsformene, og forekomsten av sykdomsprogrediering etter ti år, ble tatt med (2).

Fosså anfører videre at jeg i avslutningen formidler feilaktig informasjon angående livskvaliteten til pasientene i de ulike gruppene. Det stemmer at det i artikkelen om pasientrapporterte utfall fremgår at den helserelaterte livskvaliteten ikke var signifikant forskjellig mellom gruppene. Men det står også beskrevet forskjeller i livskvalitet spesifikt knyttet til seksualfunksjon, vannlating og mage-tarm-funksjon (3). Jeg burde, som Fosså viser, skrevet tydeligere innen hvilket område livskvaliteten ble rapportert som dårligere av pasientene i stråleterapigruppen. Det beklager jeg at ikke ble gjort.

Jeg takker for utfyllende sammenligning av funnene i forhold til behandlingspraksisen i Norge, da dette ikke ble dekket i studieomtalen. Til tross for begrenset lengde, og derav at et begrenset antall funn og vurderinger blir presentert, håper jeg Tidsskriftets lesere har glede av studieomtalene og blir inspirert av dem til å lese artiklene som omtales og til å diskutere dem i sine egne fagmiljøer.

\section{Matilde R. Berg}

m_risopatron@yahoo.es

Matilde R. Berg (f. 1985) er stipendiat ved Kirurgisk avdeling, Sykehuset Innlandet, Hamar.

Ingen oppgitte interessekonflikter.

\section{Litteratur}

1. Berg MR. Behandling eller aktiv monitorering ved prostatakreft. Tidsskr Nor Legeforen 2016; 136: 1706

2. Hamdy FC, Donovan JL, Lane JA et al. 10-year outcomes after monitoring surgery, or radiotherapy for localized prostate cancer. N Engl J Med 2016; 375 1415-24.

3. Donovan JL, Hamdy FC, Lane JA et al. Patient-reported outcomes after monitoring, surgery, or radiotherapy for prostate cancer. N Engl J Med 2016; 375: $1425-37$

\section{Re: Akutte nevrologer}

I Tidsskriftet nr. 23-24/2016 intervjues Marton König om sine fagfelt nevrologi og nevrokirurgi (1). Utvilsomt viktige fag og utvilsomt en god og entusiastisk representant! Men han bommer når han uttaler at «...det ikke er mange år siden pasienter med hjerneinfarkt... havnet på medisinske og geriatriske avdelinger... Nå er transport med luftambulanse, slagambulanse og «rød tur» i vanlig ambulanse naturlig». Det underliggende budskapet er tydelig: Behandling av hjerneslag på geriatriske og andre indremedisinske avdelinger er annenrangs og ikke noe å spandere helikopter eller «rød respons» på. Vi synes det er sørgelig at König så bastant nedvurderer andre spesialiteters kunnskap i akutt slagbehandling og overser betydningen av tverrspesialisert samarbeid.

At «tid er hjerne» og at hjerneslag skal behandles hyperakutt, har vært godt etablert i mange år. Pasienter med hjerneslag trenger alle tiltak som kan bidra til å redde hjernefunksjonen. Dette omfatter bl.a. reperfusjonsbehandling (trombolytisk behandling og trombektomi), etiologisk diagnostikk og optimal behandling av ekstracerebrale sykdommer som påvirker hjernen (og som kan forveksles med hjerneslag), umiddelbar optimalisering av generell fysiologi og legemiddelbruk, god vaskulær medisin og erfaren vurdering av potensial for reversibilitet og prognose, herunder vurdering av premorbid funksjonsnivå. Dette er oppgaver som må løses umiddelbart og parallelt, noe som krever et tillitsfullt tverrspesialisert samarbeid.

Ved Marton Königs eget sykehus, Oslo universitetssykehus, behandles heldigvis den store majoritet av pasienter med hjerneslag etter nettopp disse prinsippene. Det ville aldri falle oss indremedisinere og geriatere inn å påberope oss enerett på å behandle akutt hjerneslag, uten et nært samarbeid med nevrologer. Marton König, derimot, ser ikke ut til å være bekymret over at nevrologer skal behandle akutt hjerneslag alene, uten et nært samarbeid med geriatere eller andre indremedisinere. Det bekymrer oss.

\section{Hege Ihle-Hansen \\ hmihle@ous-hf.no \\ Torgeir Bruun Wyller}

Hege Ihle-Hansen (f. 1970) er dr.med. og seksjonsleder ved Seksjon for hjerneslag, Geriatrisk avdeling, Oslo universitetssykehus.

Ingen oppgitte interessekonflikter.

Torgeir Bruun Wyller (f. 1960) er professor ved Geriatrisk avdeling, Oslo universitetssykehus.

Ingen oppgitte interessekonflikter.

Litteratur

1. Jacobsen LD. Akutte nevrologer. Tidsskr Nor Legeforen 2016; 136: 2031

\section{König svarer:}

Jeg vil gjerne takke for kommentaren og ikke minst engasjementet knyttet til behandling av pasienter med hjerneslag. Ihle-Hansen \& Bruun Wyller har publisert bredt om behandling av hjerneslag, som har bidratt til bedre forståelse av tilstanden og på den måten til bedre behandling av pasientene.

Jeg ønsker imidlertid å komme med en oppklaring til flere av forfatternes påstander. Min intensjon var aldri å snakke nedlatende om andre kolleger eller spesialiteter. Snarere ønsket jeg med intervjuet å vekke interessen for nevrofag generelt. Min erfaring er at fagfeltet - uansett spesialitet eller yrke - dessverre kan virke skremmende på medisinstudenter og yngre leger nettopp pga. dets bredde og kompleksitet.

Jeg ser ikke på forskjellige spesialiteter som konkurrenter, men som samarbeidspartnere - nærmest som en maurtue - der alle tilstreber best mulig støtte og behandling for pasientene. Her inngår samarbeid med sykepleiere, hjelpepleiere, fysioterapeuter, ergoterapeuter, logopeder og sosionomer, bare for å nevne noen. Jeg sier 